\begin{tabular}{|c|l|}
\hline Title & Imaging the dynamics of intracellular protein translocation by photoconversion of phamret-cybr/ROM \\
\hline Author(s) & Y ang, L.; Matsuda, T.; Raviraj, V.; Ching, Y. W.; Braet, F.; Nagai, Takeharu; Soon, L. L. \\
\hline Citation & Journal of Microscopy, 242(3), 250-261 \\
\hline https://doi.org/10.1111/.1365-2818.2010.03463.x \\
\hline Issue Date & 2011-06 \\
\hline Doc URL & http://hdl.handle.net/2115/49330 \\
\hline Rights & The definitive version is available at www.blackwell-synergy.com \\
\hline Type & article (author version) \\
\hline File Information & JoM242-3_250-261.pdf \\
\hline
\end{tabular}

Instructions for use 


\title{
Imaging the dynamics of intracellular protein translocation by photoconversion of Phamret- cybr/ROM
}

\author{
L. YANG ${ }^{1}$, T. MATSUDA ${ }^{2}$, V. RAVIRAJ ${ }^{1}$, Y. W. CHING ${ }^{1}$, \\ F. BRAET ${ }^{1}$, T. NAGAI ${ }^{2}$ and L. L. SOON ${ }^{1}$
}

${ }^{1}$ Australian Key Centre for Microscopy and Microanalysis, Australian Microscopy and
Microanalysis Research Facility (AMMRF), University of Sydney, Sydney, NSW, 2006,
Australia.
${ }^{2}$ Laboratory for Nanosystems Physiology, Research Institute for Electronic Science, Hokkaido
University Kita 20, Nishi 10 Kita-ku, Sapporo 001-0020, Japan

*Correspondence to: Dr Lilian L Soon

Australian Key Centre for Microscopy and Microanalysis (AKCMM), The University of Sydney Madsen Building, F09, Room 243, NSW, 2006, Australia. Phone: 61 29351532. Fax: 612 93517682. E-mail: l.soon@usyd.edu.au

Keywords: Intracellular transport, membrane ruffling sites, photoconversion, scaffold protein. 


\begin{abstract}
Cybr/Reduced On-random Motile (ROM) is a scaffold protein, containing a postsynaptic density protein-95/discs-large/ZO-1 (PDZ) domain, a LEU region and a PDZ domain binding region at the C-terminus. In the immune system, Cybr/ROM was found to localize in vesicles and at the plasma membrane, through interactions with cytohesin-1. In this investigation, we reported Cybr/ROM as occurring in vesicles, the cytoplasm and at membrane ruffles of H1299 lung cancer cells. Its localization at the ruffles was dependent on intact actin structures as indicated by latrunculin A treatment, which abrogated ruffle formation and staining of Cybr/ROM at the cells' periphery. Transfection of truncation mutants consisting of either the PDZ or LEU domain showed that the LEU domain of ROM was localized to membrane ruffles, vesicles and the cytoplasm, whereas, the PDZ domain localized to the membrane ruffles and cytoplasm only. There was therefore, domain/molecular segregation of Cybr/ROM in different cellular compartments. Cybr/ROM was subcloned into a plasmid carrying the photoactivation-mediated resonance energy transfer (Phamret) protein. The photoconversion experiments demonstrated the diffusion of ROM from the cytoplasm to the membrane ruffling sites and conversely from membrane ruffles to the cytoplasm. Large variances in the transport velocity of Cybr/ROM in the cytoplasm suggested that its movements were facilitated by other mechanisms in addition to diffusion.
\end{abstract}




\section{INTRODUCTION}

Cybr/Reduced On-random Motile (ROM) is a 359 amino acid (aa) scaffold protein, containing a postsynaptic density protein-95/discs-large /ZO-1 (PDZ) domain, a LEU (leucine-rich) region and a PDZ domain binding region at the C-terminus. The protein-protein interaction motifs in Cybr/ROM suggest that this scaffold protein may be a component of a larger protein complex and perform multiple functions in the cell. Cybr/ROM translocates from the Golgi compartment to the plasma membrane (PM) in a cytohesin dependent way with EGF stimulation in COS-1 cells (Mansour et al., 2002). It is also recruited to the PM of Jurkat cells in a $\beta 2$ integrindependent fashion and actively sequesters its binding partner, the integrin-activating protein cytohesin-1, to the cytoplasm (Boehm et al., 2003). In COS-1 cells, Cybr/ROM partially overlaps with the ER/Golgi intermediate marker ERGIC-53 and is capable of interacting with cytohesin-1, ARNO and ARNO3, which are associated with the Golgi (Lee \& Pohajdak, 2000; Mansour et al., 2002). Cybr/ROM is recruited from the Golgi compartment to membrane ruffling sites in a cytohesin-dependent manner, which suggests that Cybr/ROM may play a role in ARF-mediated vesicle formation and regulate or facilitate a specialized aspect of vesicle transport that involves at least one member of the cytohesin family in hematopoietic cells (Mansour et al., 2002). Cybr/ROM has vesicular localization within the cytoplasm and at the nuclear periphery in myometrial smooth muscle cells (O’Brien et al., 2008). Cybr/ROM partially co-localized with tubulovesicular structures suggesting that it occurred in more than one cellular compartment (Mansour et al., 2002).

Cybr/ROM is also known as cytohesin binder and regulator (Cybr) (Tang et al., 2002; Boehm et al., 2003), cytohesin-1 interacting protein (CYTIP) (Boehm et al., 2003), cytohesinassociated scaffolding protein (CASP) (Mansour et al., 2002), cytohesin-binding protein (CBP) 
(Kitano et al., 2002) and ROM (Tchou-Wong et al., 2006). It is similar to the sequence of B3-1, which is renamed as pleckstrin homology, Sec 7 and coiled coil domains, binding protein (PSCDBP), but somewhat longer and with a different start codon (Dixon et al., 1993; Kim et al., 1999; Heufler et al., 2008). Cybr/ROM has a closely related homologue known as GRASP (mouse)/tamalin (rat), sharing an overall 50\% sequence homology and similar domains (Nevrivy et al., 2000). The mRNA of PSCDBP increase 2-fold in NK/T cells upon stimulation with interleukin-2 and interleukin-12 (Dixon et al., 1993). In chemokinetic cells, which are less adhesive and favour faster motility speed than control cells, Cybr/ROM expression is reduced by over 3-fold (Tchou-Wong et al., 2006). Cybr/ROM is increased at least 20-fold during dendritic cell maturation (Heufler et al., 2008) and 10-fold in the human myometrium at labour (O'Brien et al., 2008).

Cybr/ROM expression is highest in organs of the immune system, such as thymus, spleen, peripheral blood leukocytes, lymph node and bone marrow, and it is differentially regulated by cytokines at different stages of T-lymphocyte development (Coppola et al., 2006). Cybr/ROM is also expressed to some extent in lung, kidney and testis (Dixon et al., 1993; Tang et al., 2002; Coppola et al., 2006). Lung cancer cells are however, downregulated in Cybr/ROM transcript levels, which is associated with an increase in random motility and cell invasiveness (TchouWong et al., 2006).

In this study, we explored the domain-specific regulation of Cybr/ROM transport and the dynamics of transport events occurring between subcellular compartments. We demonstrate Cybr/ROM localization in lung cancer cells by constructing GFP-Cybr/ROM plasmids and performing transient transfections into H1299 lung cancer cells. The results show that Cybr/ROM localizes on membrane ruffles and in vesicles of H1299 cells. The membrane ruffle localization 
of Cybr/ROM was abrogated in latrunculin A treated cells. We also verify that Cybr/ROM vesicular trafficking and membrane ruffle localization are events that are partially mutually exclusive. Furthermore, we investigated the transport dynamics of Cybr/ROM between the cytoplasm and the membrane ruffling sites in H1299 cells by using the photoconvertable photoactivation-mediated resonance energy transfer (Phamret) fluorophore with Fluorescence Resonant Energy Transfer (FRET). Phamret is a monomeric photoconvertible fluorescent protein, that requires only one wavelength to excite both the pre- and post-photoconverted states, thus enabling quantitative observation of rapidly diffusible molecules (Patterson \& LippincottSchwartz, 2002; Matsuda et al., 2008). We show that Phamret-Cybr/ROM is transported from the cytoplasm to membrane ruffles and that the reverse is also true. This movement of Cybr/ROM has never been directly illustrated but has been inferred indirectly based on its functional domains and from biochemical studies (Boehm et al., 2003). 


\section{MATERIALS AND METHODS}

\section{Cell culture and transfection}

H1299 cells were cultured in Dulbecco's Modified Eagle Medium (DMEM) (Invitrogen/Gibco, Carlsbad, CA, U.S.A.) supplemented with 5\% fetal bovine serum (FBS) (BD Biosciences Bedford, MA, U.S.A.), penicillin and streptomycin (Invitrogen).

H1299 cells were transiently transfected with GFP control vector or GFP-Cybr/ROM. The photoconversion experiments required the transfection of plasmids containing Phamret alone or Phamret-Cybr/ROM. Cells were trypsinized, counted $\left(1.0 \times 10^{5}\right.$ cells in each culture dish $)$ and seeded on $22 \times 22 \mathrm{~mm}$ glass coverslips or on $60 \times 15 \mathrm{~mm}$ tissue culture dishes for $24 \mathrm{~h}$ at $37^{\circ} \mathrm{C}$ in

a humidified $5 \% \mathrm{CO}_{2}$ incubator. Transfections were carried out using $0.5 \mu \mathrm{g} \mu \mathrm{L}^{-1}$ of DNA and Lipofectamine2000 (LF2000) (Invitrogen).

\section{cDNA cloning and sequence analysis}

Clonal cell lines were established using zeocin (Invitrogen) as the selection marker. Control cell lines were also generated by transfection with the empty vector. Full-length Cybr/ROM was cloned from cDNA derived from brain tissue (Clontech Laboratories, Mountain View, CA, U.S.A.) High fidelity enzymes and gene specific primers: $5^{\prime}$-TCTTTACAA AGGCTCCTGCAACACAGCAGC and 3' -AATCCGTCAAAAGCGACTTTCTTCCTCTTCC were used in a PCR reaction to obtain the gene fragment which was subsequently cloned into an Express-tagged vector, pcDNA4.1 (Invitrogen). 
Truncation mutants consisting of the PDZ domain only (aa 77 - 166) or the LEU domain (aa 167 - 188) were generated by PCR cloning using the following primer sets: sense primers $5^{\prime}$-TCTTTACAAAGGCTCCTGCAACACAGCAGC-3 ' , antisense primers $5^{\prime}$ TCACTCCGTTCTTTTCAGAATCATTGTTCCATTAA-3 ' ${ }^{\prime}$ and sense primers $5{ }^{\prime}$ CTGAAAAGAACGGAGCTTGAAGCAAAGCTGCAG-3 ' and anti sense primers $5^{\prime}$ TTATTCCTCTTCCACAGCACGATGAAGGCC-3' (Invitrogen).

To generate fused Phamret and ROM plasmids, the gene of ROM was amplified by PCR with the sense primers: 5' -CGGAATTCGGTGGCAGCGGTGGCTCTTTACAAAGGCTCCT$3^{\prime}$ and antisense primers $5^{\prime}$-CATCGCCTCGAGTCAAAAGCGACTTTCTTCC-3 ' (Invitrogen) and then subcloned into the Phamret-PCDNA3 vector driven by the cytomegalovirus immediate-early promotor that expresses the gene in eukaryotic cells (Fig. S1).

All clones used have been verified by sequencing and sequence alignment was performed with the BLAST program (National Center of Biotechnology Information, Bethesda, MD, U.S.A.).

\section{Cell fractionation and western blotting}

GFP and GFP- Cybr/ROM transiently transfected H1299 cells were incubated for $24 \mathrm{~h}$. Cell pellets were resuspended in $100 \mu \mathrm{L}$ of ice cold lysis buffer $(100 \mathrm{~mm} \mathrm{NaF}, 0.5 \% \mathrm{NP}-40,120 \mathrm{~mm}$ $\mathrm{NaCl}, 50$ mm Tris-HCl (pH 8.0), $200 \mu \mathrm{m} \mathrm{Na}_{3} \mathrm{VO}_{4}$ (Sigma-Aldrich Corp., St. Louis, MO, U.S.A.) with one complete protease inhibitor cocktail (Sigma-Aldrich) and $100 \mu \mathrm{g}$ leupeptin (Sigma- 
Aldrich) added to $10 \mathrm{~mL}$ of lysis buffer immediately before use. The cell lysates were centrifuged at $10000 \mathrm{~g}$ for $15 \mathrm{~min}$ to remove nuclei and unlysed cells. The supernatants were transferred to new tubes and centrifuged for $45 \mathrm{~min}, 4^{\circ} \mathrm{C}$ at $126000 \mathrm{~g}$ to separate $\mathrm{PM}$ and cytoplasmic fractions. After electrophoresis, proteins were transferred to PVDF membrane for Western blots. Primary antibodies used for detection of protein were mouse anti- $\beta$-catenin (BD Biosciences) and mouse anti-GFP (B-2) (Santa Cruz Biotechnology, Santa, Cruz, CA, U.S.A.). The secondary antibody used was Horseradish Peroxidase (HRP) conjugated goat anti-mouse (Pierce, Rockford, IL, U.S.A.).

\section{Microscopy}

An Olympus FV1000 confocal laser scanning microscope (Olympus, Tokyo, Japan) equipped with a SIM scanner, which allowed for simultaneous stimulation and imaging, and a $60 \times$ water objective lens was used for photoconversion experiments and to acquire images. Leibovitz L15 (L15) medium (Invitrogen) containing 5\% FBS was used for live cell imaging. To perform the photoconversion, a $405 \mathrm{~nm}$ laser was used on a defined region of interest (ROI) for $38 \mathrm{~ms}$. Cyan and green fluorescence signals were acquired by excitation at $458 \mathrm{~nm}$ and detected at $485-500$ $\mathrm{nm}$ and $500-550 \mathrm{~nm}$ wavelength ranges, respectively. The scan rate was $4.0 \mu \mathrm{s}$ pixel- -1 . The

resolution of the images was $512 \times 512$ pixels. The pixel size was $0.138 \mu \mathrm{m}$ pixel-1. For photobleaching experiments, the $515 \mathrm{~nm}$ laser was used to bleach the green channel for $2 \mathrm{~s}$. The psuedocoloured images were created by AquaCosmos 2.6 software (Hamamatsu Photonics, Shizuoka Pref., Japan). To view recordings of the experiments and to calculate ROM's transport 
velocity in H1299 cells, the $405 \mathrm{~nm}$ laser was used on ROI for $1 \mathrm{~ms}$. The scan rate was $0.5 \mu \mathrm{s}$ pixel-1. The resolution of the images was $256 \times 256$ pixels. The pixel size was $0.138 \mu \mathrm{m}$ pixel-1. A ROI (radius $=0.5 \mu \mathrm{m}$ ) was drawn on the photoconverted region within the cytoplasm and ROIs (radius $=0.5 \mu \mathrm{m}$ ) were also placed on the PM and within the cytoplasm $1 \mu \mathrm{m}$ away from the photoconverted region. Four-second time course images were taken every $65 \mathrm{~ms}$. The time course of green to cyan emission ratio in all ROIs was recorded. The transport time was calculated using the formula

$$
\mathrm{t}=\mathrm{t}_{\mathrm{ROI}}-\mathrm{t}_{\mathrm{PC}}
$$

where $t$ is the transport time of Phamret-Cybr/ROM, tROI was the time the ROIs attained the highest green to cyan emission ratio, tPC was the time the photoconverted area reached the highest green to cyan emission ratio. The velocity was calculated by dividing the distance between the ROIs and the photconverted area by the transport time, as described before (Hoogland et al., 2009). The variance of Cybr/ROM transport velocity was performed with Bartlett's test.

The duration of occurrence at the PM was calculated using the formula

$$
\mathrm{T}=\mathrm{t}_{1 / 2}-\mathrm{t}_{\mathrm{ROI}}
$$

where $T$ is the duration, $t_{1 / 2}$ is the time of the selected PM area emission ratio decreased to half of the maximum after photoconversion. 


\section{RESULTS}

\section{Cybr/ROM occurred in vesicles and at the membrane ruffling sites of H1299 lung cancer cells}

In order to segregate the cytoplasmic and membrane components of Cybr/ROM, the gene was conjugated to a vector carrying the GFP gene and the construct was transiently transfected into H1299 lung cancer cells. Fractionation experiments were performed by centrifugation of lysed cells at varying speeds, electrophoresis of the cellular components and immunoblotting using an antibody recognizing GFP. The data illustrated that Cybr/ROM can be found in the cytoplasmic and membrane fractions (Fig. 1A). As a positive control, $\beta$-catenin antibodies were used in the immunoblots and the results showed segregation of the protein into the different cellular compartments and its primary presence at the PM. To further distinguish between membrane components, live-cell imaging of cells transiently transfected with GFP-Cybr/ROM was performed. The data showed the localization of Cybr/ROM to membrane ruffles, the cytoplasm and also to vesicles that shuttled within the cell cytoplasm (Fig. 1B and Movie S1).

To test whether the membrane ruffling site localization of Cybr/ROM is similar to the pattern of actin filaments at the leading edges of the cell, latrunculin A, an actin monomerbinding toxin, was used to treat cells transfected with GFP-Cybr/ROM $1 \mathrm{~h}$ prior to imaging in live-mode. The data demonstrated that the membrane ruffling site localization of Cybr/ROM was lost in latrunculin A-treated cells (Fig. 1C), suggesting coincidence with actin-regulated ruffling at the cell's leading edge. 
The LEU domain determines membrane ruffles and vesicular presence whereas the PDZ domain dictates membrane ruffles and cytoplasmic localization in $\mathrm{H1299}$ cells

Cybr/ROM has several domains that might be differentiated functionally in the targeting of the protein to various cellular compartments. To test this, Cybr/ROM was cloned into a GFPexpressing vector that was subsequently used to generate domain truncated mutants by PCR amplification. The mutants expressing the PDZ and LEU domains in GFP vectors were transfected into H1299 lung cancer cells. Wild-type Cybr/ROM demonstrated localization to the membrane ruffling sites, vesicles and the cytoplasm while LEU mutants remained localized to vesicles and membrane ruffles (Fig. 2). The PDZ, mutants, however, showed loss of staining at vesicles but were localized to membrane ruffles with increased presence in the cytoplasm relative to control cells. The data suggested that transport of Cybr/ROM occurring via the LEU domain was specific to at least a portion of the vesicles but the PDZ domain alone was insufficient to drive vesicular localization. Both the LEU and PDZ domains however, promote protein localization to membrane ruffles.

\section{Cloning of ROM into Phamret, a photoconvertible protein, and demonstration of photoconversion using spectral imaging}

It is possible that Cybr/ROM was transported to the membrane ruffling sites directly for interactions with proteins that bind to its various domains. While Cybr/ROM has been shown to function at the membrane ruffling sites by sequestering and translocating cytohesin- 1 to the cytoplasm, its transport to the ruffles has not been thoroughly investigated. In order to demonstrate membrane translocation of Cybr/ROM and to quantify the dynamics of the event, 
the gene of Cybr/ROM was cloned into a photoconvertible product, Phamret, (Fig. S1) for tracking studies. Phamret is composed of a cyan fluorescent protein variant (mse-CFP) connected to Photoactivatable GFP (PA-GFP). The mse-CFP contains a C-terminal 11-aa truncation while the PA-GFP has a 3-aa truncation from the $\mathrm{N}$ terminus. In addition, PA-GFP contains a histidine mutation at the threonine 203 position of wild-type GFP (T203H) (Patterson \& LippincottSchwartz 2002). The fluorescent proteins are connected via a dipeptide (Gly-Thr) linker (Matsuda et al., 2008). Phamret was activated by UV light so that subsequent excitation at 458 $\mathrm{nm}$ resulted in elevated emission levels in the green channel at the expense of the cyan channel (Fig. 3A).

In order to verify the photoconversion process, H1299 cells were transiently transfected with Phamret or Phamret-Cybr/ROM constructs for spectral imaging using the Olympus FV1000 microscope equipped with a SIM scanner. Measurements were obtained across a spectral window of between $480 \mathrm{~nm}$ and $700 \mathrm{~nm}$ at $5 \mathrm{~nm}$ bandwidth intervals. Following activation of Phamret, the intensity maximum in the emission channel shifted from $485 \mathrm{~nm}$ to $510 \mathrm{~nm}$, indicating successful photoconversion (Fig. 3B). In parallel experiments, Phamret-Cybr/ROM was transfected into H1299 cells and following photoconversion, a similar spectral shift was detected as illustrated (Fig. 3C).

\section{Photoconversion of Phamret and Phamret-ROM in H1299 cells.}

H1299 cells were grown for $24 \mathrm{~h}$, transfected with the photoconvertible constructs and used in live imaging studies. A ROI was drawn within the cell cytoplasm, and was activated using the $405 \mathrm{~nm}$ laser of the SIM scanner, while simultaneously imaging with the $458 \mathrm{~nm}$ laser in the 
confocal system (Fig. 4). Photoactivated Phamret and Phamret-Cybr/ROM rapidly distributed across the cell cytoplasm, and this was traced by drawing ROIs in different regions of the cell and tracking the intensities over time in the two channels. In the preconversion state, the cell appeared bright in the cyan channel but dim in the green channel. Following photoconversion, the cell increased its intensity regionally over time in the green channel. This was also demonstrated by the cyan - green ratio image illustrated in pseudocolour where the mse-CFP and PA-GFP fluorescence were represented by cyan and red, respectively. The photoconversion of Phamret and Phamret-Cybr/ROM was further verified as occurring via FRET between the mse-CFP and PA-GFP proteins by bleaching the photoconverted cells in the green channel and monitoring the recovery of fluorescence in the cyan channel. Following photoconversion, the ROI was photobleached using the $515 \mathrm{~nm}$ laser for $2 \mathrm{~s}$, while measuring the fluorescence intensities by scanning with the $458 \mathrm{~nm}$ laser and imaging in both the cyan and green channels. While the green channel showed loss of fluorescence due to photobleaching, the cyan channel demonstrated recovery from fluorescence loss.

The events were also illustrated when graphed as histograms where a $40 \%$ loss in intensity in the cyan channel followed by a $10 \%$ recovery level was observed for Phamret. Conversely, a $35 \%$ gain occurred in the green channel after photoconversion and a $20 \%$ loss was observed after photobleaching. Similar observations were made for Phamret-Cybr/ROM. Three independent experiments were performed using at least five cells each time (Fig. 4C and D).

\section{Phamret-Cybr/ROM but not Phamret translocated to the membrane ruffles}


Having verified the photoconvertibility of Phamret and Phamret-Cybr/ROM, it became feasible to test the utility of the proteins in functional assays. H1299 lung cancer cells were transiently transfected with the constructs and subjected to photoconversion and tracking studies. A ROI was drawn within the cell cytoplasm and activated using the SIM scanner. Another ROI was drawn on the membrane ruffling sites. Imaging was concurrently performed with the $458 \mathrm{~nm}$ laser and the intensity changes were recorded over time. The ratios of green to cyan channel emission in the ROIs were calculated and the cyan-green ratio images were illustrated in pseudocolour. In the Phamret transfected cells, the ratio of the ROI on membrane ruffles showed no change over time (Fig. 5A). However, in the Phamret-Cybr/ROM-transfected cells, the ratio was increased after photoconversion (Fig. 5B). The results indicated that Phamret-Cybr/ROM migrated from the cytoplasm to membrane ruffles in H1299 cells, but this was not the case for the control Phamret vector.

Whether Phamret-Cybr/ROM at membrane ruffles may migrate to the cytoplasm was also tested. A ROI was drawn on the membrane ruffling sites of the Phamret-Cybr/ROM transfected H1299 cells and activated using the SIM scanner (Fig. 6). Other ROIs were drawn on membrane ruffles and within the cytoplasm. The ratios of the ROIs on the membrane ruffling sites and within the cytoplasm were all increased after photoconversion, which indicated that PhamretCybr/ROM migrated along membrane ruffles and from the ruffles to the cytoplasm.

To test the transport velocity of Cybr/ROM in H1299 cells, Phamret-Cybr/ROM was transiently transfected into H1299 cells. Images were taken at every $65 \mathrm{~ms}$ and rapid photoconversion (1 ms) was performed using a $405 \mathrm{~nm}$ light source. In order to achieve the relatively high frequency of frames captured, the scan speed was increased, the size of the image was minimalized to $256 \times 256$ pixels, and single scans (without averaging) were performed. 
These parameters were chosen to enable the tracking of vesicle movements while preserving sufficient resolution to distinguish cellular structures. Therefore, maximizing the speed of image acquisition comes with some sacrifice to resolution.

A ROI (radius $=0.5 \mu \mathrm{m}$ ) was drawn on the photoconverted region within the cytoplasm. ROIs (radius $=0.5 \mu \mathrm{m}$ ) were also placed on membrane ruffles and within the cytoplasm with a defined distance $(1 \mu \mathrm{m})$ from the photoconverted region. The time course of green to cyan emission ratio in all ROIs was recorded. The transport velocity of Cybr/ROM is $4.9 \pm 0.7 \mu \mathrm{m} \mathrm{s}^{-1}$ (mean \pm SEM; $\mathrm{n}=20$, range from 2.2 to $15.4 \mu \mathrm{m} \mathrm{s}^{-1}$ ) within the cytoplasm. The transport of Cybr/ROM from the cytoplasm to the membrane ruffling sites occurs at a similar velocity of 4.3 $\pm 0.3 \mu \mathrm{m} \mathrm{s}^{-1}$ (mean \pm SEM; $\mathrm{n}=20$, range from 2.6 to $7.7 \mu \mathrm{m} \mathrm{s}^{-1}$ ). The variance of Cybr/ROM velocity within the cytoplasm was significantly larger than that from the cytoplasm to the membrane ruffling sites (analysed with Bartlett's test, $\mathrm{P}=0.03$ ). Furthermore, $\mathrm{Cybr} / \mathrm{ROM}$ is stable at the membrane ruffling sites for $0.110 \pm 0.018 \mathrm{~s}$ (mean \pm SEM; $n=20$, range from 0.065 to $0.195 \mathrm{~s}$ ) (Table 1).

\section{Phamret-ROM but not Phamret translocated to the PM}

Having verified the photoconvertibility of Phamret and Phamret-ROM, it became feasible to test the utility of the proteins in functional assays. H1299 lung cancer cells were transiently transfected with the constructs and subjected to photoconversion and tracking studies. A ROI was drawn within the cell cytoplasm and activated using the SIM scanner. Imaging was concurrently performed with the $458 \mathrm{~nm}$ laser and the intensity changes were recorded over time. The results 
indicated that the photoconverted products migrated from the cytoplasm to the PM in PhamretROM-transfected cells but this was not the case for control cells transfected with the Phamret vector (Fig. 6, 7). When Phamret-ROM at the PM was photoconverted, there was dissipation of green fluorescence into the cytoplasm and along the PM (Fig. 8 and Table 1).

Table 1

\begin{tabular}{|c|c|c|}
\hline & Mean \pm SEM & Range of measurements \\
\hline The velocity of ROM within cytoplasm $\left(\mu \mathrm{m} \mathrm{s}^{-1}\right)$ & $4.9 \pm 0.7$ & $2.2-15.4^{*}$ \\
\hline The velocity of ROM from cytoplasm to PM $\left(\mu \mathrm{m} \mathrm{s}^{-1}\right)$ & $4.3 \pm 0.3$ & $2.6-7.7^{*}$ \\
\hline Duration of ROM occurrence at the PM $(\mathrm{s})$ & $0.110 \pm 0.018$ & $0.065-0.195$ \\
\hline
\end{tabular}

Table 1. The analysis of Cybr/ROM transport velocity and duration in H1299 cells. 


\section{DISCUSSION}

Cybr/ROM's presence at the PM and association with the trafficking pathway signal a possible function in the distribution of membrane-targeted proteins-for example, CYTIP/ROM binding to cytohesin-1 drives the latter from the PM to the cytoplasm in an integrin-dependant manner (Boehm et al., 2003). We sought to further evaluate the spatial regulation of Cybr/ROM distribution by constructing truncation mutants to $\mathrm{Cybr} / \mathrm{ROM}$ followed by expression in mammalian cells. While the LEU domain mutant localizes to membrane ruffles and vesicles, the PDZ domain labels ruffles and the cytoplasm, lacking vesicular localization. This demonstrates that membrane ruffling and vesicle trafficking are partially segregated in terms of domain/molecular regulation. Furthermore, membrane ruffle localization dynamics of Cybr/ROM was further explored using photoconversion; this technique allows a small area of the cell to be illuminated, thus activating only a fraction of cellular fluorophores. The fluorophores highlighted by photoconversion can then be tracked to new positions within the cell in a different fluorescent channel. The use of Phamret, a photoconvertible protein, allows rapid data acquisition through the ability to excite both pre and post converted states using a single laser line (Matsuda et al., 2008). Cybr/ROM was conjugated to Phamret in a mammalian expression vector. Following activation by UV light, and excitation with $458 \mathrm{~nm}$ laser light, energy transfer occurs from the CFP to PA-GFP proteins, significantly increasing the intensity in the green channel. Unactivated proteins remain dim in this channel. Phamret-Cybr/ROM functions in the same way and demonstrates a similar spectral shift in the emission channel after photoconversion. It is possible to monitor the movement of $\mathrm{Cybr} / \mathrm{ROM}$ to the membrane ruffling sites directly, which is previously not achievable using GFP-Cybr/ROM or other staining techniques. The dynamics of Cybr/ROM's movement to and from the inner aspect of the cell surface is recorded. Cybr/ROM is 
stable at membrane ruffles for $0.110 \mathrm{~s}$, suggesting that it may be tethered by some means before translocating back into the cytoplasm. The average velocities of Cybr/ROM transport within the cytoplasm and from the cytoplasm to membrane ruffles are similar. However, the variance of Cybr/ROM transport velocity within the cytoplasm is significantly larger than that from the cytoplasm membrane ruffles. Therefore, Cybr/ROM may not simply be freely diffusible in the cytoplasm suggesting that it could interact with other proteins or organelles, altering or varying the rates of movement in this cellular compartment.

Cybr/ROM is an adaptor protein and its various domains have differing functions that are not completely characterized. We show that both the PDZ and LEU domains can commonly regulate or affect membrane ruffle localization of the protein. Binding to members of the ARNO family of ARF effectors, cytohesin-1, ARNO and ARNO3, is one method by which Cybr/ROM is transferred to the PM (Mansour et al., 2002). The cytohesins are able to interact with membrane phospholipids at the PM through a C-terminal PH domain (Venkateswarlu et al., 1998; Venkateswarlu et al., 1999; Klarlund et al., 2000) and with Cybr/ROM via coiled coil motifs present on both interacting partners (Mansour et al., 2002). Therefore, the LEU domain of Cybr/ROM (containing a coiled coil motif) affecting protein localization to both membrane ruffles and a fraction of Cybr/ROM-labelled vesicles, might be regulated through interactions with the cytohesins. The PDZ domain of $\mathrm{Cybr} / \mathrm{ROM}$, however, has unknown binding partners and also localizes Cybr/ROM to membrane ruffles and the cytoplasm but not to vesicles. Therefore, the PDZ domain may have a different mechanism of transporting Cybr/ROM to membrane ruffles compared to the LEU domain and does not participate in the vesicle trafficking functions of Cybr/ROM. 
A hint to the function of the PDZ domain comes from studies on tamalin, a protein homologue, which interacts with TrkCT1 via the PDZ domain for PM localization. In HEK293 cells, Neurotrophin-3 (NT3) stimulation promotes the formation of a TrkCT1-tamalin complex, which activates ARF6 and Rac1 GTPase, resulting in membrane ruffling and the formation of cellular protrusions (Mouneimne et al., 2004; Soon et al., 2005; Esteban et al., 2006; Mouneimne et al., 2006; Soon, 2007; Fok et al., 2008; DesMarais et al., 2009). Therefore, there could be similar functions for the PDZ domain of $\mathrm{Cybr/ROM}$ in parallel membrane targeting and actin polymerization pathways involving ARF6 and Rac.

Another reference to the function of the PDZ domain is related to cell adhesion in Jurkat cells (Boehm et al., 2003). This domain is required for Cybr/ROM localization to the cell cortex in an integrin-dependent manner. The presence of Cybr/ROM at the PM, however, is disrupted when the cells are activated by phorbol esters leading to Cybr/ROM translocation to the cytoplasm and concomitant loss of cell-matrix adhesion. The interruption in the molecular links that promote cell adhesion is mediated through sequestering of cytohesin-1 from the PM by Cybr/ROM. These observations suggest a function of Cybr/ROM in transendothelial migration, a process requiring the regulation of adhesion and de-adhesion of cells (Boehm et al., 2003).

Our earlier findings showed that low ROM levels are linked to weaker adhesion of lung cancer cells to substrate, random-walking under globally stimulated conditions and increases in basal cell migration (Tchou-Wong et al., 2006). It remains to be determined how the various ways that Cybr/ROM affect cell signalling, adhesion, polarity and migration are linked. Future work in identifying the PDZ-domain binding partners will greatly assist in understanding the molecular connections between the different cellular process controlled by Cybr/ROM. Dynamic imaging studies such as performed in this paper will play an important role in elucidating the 
temporal and spatial changes in Cybr/ROM-protein complexes that relate to switches in biological functions. The latter might include alterations from unpolarized to polarized cells with a stable protrusion, cell adhesion and de-adhesion, and directional as opposed to random cell migration.

In conclusion, the data suggest that Cybr/ROM localizes on membrane ruffles and vesicles in H1299 cells. The membrane ruffling sites and vesicular localization of Cybr/ROM are differentially regulated by the PDZ and LEU domains. There is therefore, spatial and molecular segregation of Cybr/ROM function in the two compartments. The intracellular dynamics of Cybr/ROM transport was further explored using photoconversion experiments. The data show the transport of Cybr/ROM as occurring from the cytoplasm to membrane ruffles and conversely from the ruffling sites to the cytoplasm. This work can lead to future investigations to elucidate how altered membrane targeting of $\mathrm{Cybr} / \mathrm{ROM}$ may affect cell polarity and directionality of movement during cell migration. 


\section{ACKNOWLEDGEMENT}

This study has been supported by the National Health and Medical Research Council (NHMRC; \# 402510; Soon), Australia, the Australian Research Council (ARC; \# DP0881012; Soon), Australia, and FABLS. We also gratefully acknowledge the Australian Centre for Microscopy and Microanalysis (ACMM), for staff assistance, particularly Dr. Renee Whan and Mr. Dennis Drawte, and utilization of the facility. 


\section{REFERENCESS}

Boehm, T., Hofer, S., Winklehner, P., et al . (2003) Attenuation of cell adhesion in lymphocytes is regulated by CYTIP, a protein which mediates signal complex sequestration. EMBO J. 22, $1014-1024$.

Coppola, V., Barrick, C.A., Bobisse, S., et al . (2006) The scaffold protein Cybr is required for cytokine-modulated trafficking of leukocytes in vivo. Mol. Cell. Biol. 26, 5249-5258.

DesMarais, V., Yamaguchi, H., Oser, M., Soon, L., Mouneimne, G., Sarmiento, C., Eddy, R. \& Condeelis, J. (2009) N-WASP and cortactin are involved in invadopodium-dependent chemotaxis to EGF in breast tumor cells. Cell. Motil. Cytoskeleton 66, 303-316.

Dixon, B., Sahely, B., Liu, L. \& Pohajdak, B. (1993) Cloning a cDNA from human NK/T cells which codes for an unusual leucine zipper containing protein. Biochim. Biophys. Acta 1216, 321324.

Esteban, P.F., Yoon, H.Y., Becker, J., et al . (2006) A kinase-deficient TrkC receptor isoform activates Arf6-Rac1 signaling through the scaffold protein tamalin. J. Cell. Biol. 173, 291-299.

Fok, S., Domachuk, P., Rosengarten, G., Krause, N., Braet, F., Eggleton, B.J. \& Soon, L.L. (2008) Planar microfluidic chamber for generation of stable and steep chemoattractant gradients. Biophys. J. 95, 1523-1530.

Heufler, C., Ortner, D. \& Hofer, S. (2008) Cybr, CYTIP or CASP: an attempt to pinpoint a molecule's functions and names. Immunobiology 213, 729-732.

Hoogland, T.M., Kuhn, B., Gobel, W., Huang, W., Nakai, J., Helmchen, F., Flint, J. \& Wang, S.S. (2009) Radially expanding transglial calcium waves in the intact cerebellum. Proc. Natl. Acad. Sci. U.S.A. 106, 3496-3501.

Kim, H.G., Kassis, J., Souto, J.C., Turner, T. \& Wells, A. (1999) EGF receptor signaling in prostate morphogenesis and tumorigenesis. Histol. Histopathol. 14, 1175-1182.

Kitano, J., Kimura, K., Yamazaki, Y., Soda, T., Shigemoto, R., Nakajima, Y. \& Nakanishi, S. (2002) Tamalin, a PDZ domain-containing protein, links a protein complex formation of group 1 metabotropic glutamate receptors and the guanine nucleotide exchange factor cytohesins. $J$. Neurosci. 22, 1280-1289.

Klarlund, J.K., Tsiaras, W., Holik, J.J., Chawla, A. \& Czech, M.P. (2000) Distinct polyphosphoinositide binding selectivities for pleckstrin homology domains of GRP1-like proteins based on diglycine versus triglycine motifs. J. Biol. Chem. 275, 32816-32821.

Lee, S. Y. \& Pohajdak, B. (2000) N-terminal targeting of guanine nucleotide exchange factors (GEF) for ADP ribosylation factors (ARF) to the Golgi. J. Cell Sci. 113(Pt 11), 1883-1889. 
Mansour, M., Lee, S.Y. \& Pohajdak, B. (2002) The N-terminal coiled coil domain of the cytohesin/ARNO family of guanine nucleotide exchange factors interacts with the scaffolding protein CASP. J. Biol. Chem. 277, 32302-32309.

Matsuda, T., Miyawaki, A. \& Nagai, T. (2008) Direct measurement of protein dynamics inside cells using a rationally designed photoconvertible protein. Nat. Methods 5, 339-345.

Mouneimne, G., DesMarais, V., Sidani, M., Scemes, E., Wang, W.G., Song, X.Y., Eddy, R. \& Condeelis, J. (2006) Spatial and temporal control of cofilin activity is required for directional sensing during chemotaxis. Curr. Biol. 16, 2193-2205.

Mouneimne, G., Soon, L., DesMarais, V., et al . (2004) Phospholipase C and cofilin are required for carcinoma cell directionality in response to EGF stimulation. J. Cell Biol. 166, 697-708.

Nevrivy, D.J., Peterson, V.J., Avram, D., et al . (2000) Interaction of GRASP, a protein encoded by a novel retinoic acid-induced gene, with members of the cytohesin family of guanine nucleotide exchange factors. J. Biol. Chem. 275, 16827-16836.

O'Brien, M., Morrison, J.J. \& Smith, T.J. (2008) Upregulation of PSCDBP, TLR2, TWIST1, FLJ35382, EDNRB, and RGS12 gene expression in human myometrium at labor. Reprod. Sci. 15, 382-393.

Patterson, G.H. \& Lippincott-Schwartz, J. (2002) A photoactivatable GFP for selective photolabeling of proteins and cells. Science 297, 1873-1877.

Soon, L., Mouneimne, G., Segall, J., Wyckoff, J. \& Condeelis, J. (2005) Description and characterization of a chamber for viewing and quantifying cancer cell chemotaxis. Cell Motil. Cytoskeleton 62, 27-34.

Soon, L.L. (2007) A discourse on cancer cell chemotaxis: Where to from here IUBMB Life 59, $60-67$.

Tang, P., Cheng, T.P., Agnello, D., et al . (2002) Cybr, a cytokine-inducible protein that binds cytohesin-1 and regulates its activity. Proc. Natl. Acad. Sci. U.S.A. 99, 2625-2629.

Tchou-Wong, K.M., Fok, S.Y., Rubin, J.S., Pixley, F., Condeelis, J., Braet, F., Rom, W. \& Soon, L.L. (2006) Rapid chemokinetic movement and the invasive potential of lung cancer cells; a functional molecular study. BMC Cancer 6, 151.

Venkateswarlu, K., Gunn-Moore, F., Oatey, P.B., Tavare, J.M. \& Cullen, P.J. (1998) Nerve growth factor- and epidermal growth factor-stimulated translocation of the ADP-ribosylation factor-exchange factor GRP1 to the plasma membrane of PC12 cells requires activation of phosphatidylinositol 3-kinase and the GRP1 pleckstrin homology domain. Biochem. J. 335(Pt 1), 139-146.

Venkateswarlu, K., Gunn-Moore, F., Tavare, J.M. \& Cullen, P.J. (1999) EGF-and NGFstimulated translocation of cytohesin-1 to the plasma membrane of PC12 cells requires PI 3kinase activation and a functional cytohesin-1 PH domain. J. Cell. Sci. 112(Pt 12), 1957-1965. 


\section{FIGURE LEGENDS}

Figure 1. Cybr/ROM localized to vesicles, within the cell cytoplasm and at membrane ruffles. (A) H1299 cells were transiently transfected with GFP-Cybr/ROM plasmids for $24 \mathrm{~h}$ and then lysed. The cell lysate was centrifuged at varying speeds to separate cellular components, electrophoresed, the proteins transferred to PVDF membranes and immunoblotted with anti-GFP (Lanes 1, 2) and anti $\beta$-catenin antibodies (Lanes 3, 4). The data showed Cybr/ROM localization to the plasma membrane (PM) and cytoplasm of H1299 cells. (B) H1299 cells were seeded on rat type I collagen-coated glass bottom dishes for $24 \mathrm{~h}$ and transiently transfected with GFPCybr/ROM plasmids. After a $24 \mathrm{~h}$ incubation, live cell imaging was performed on the Olympus FV1000 laser scanning microscope with a $60 \times$ water objective. Confocal and DIC images showed that Cybr/ROM localized to vesicles (arrowhead) and at membrane ruffles (arrow) of H1299 cells. (C) GFP-Cybr/ROM transfected H1299 cells were incubated for $24 \mathrm{~h}$ and then treated with $25 \mu \mathrm{g} \mathrm{mL}-1$ of the actin monomer-binding toxin, latrunculin $\mathrm{A}$, for $1 \mathrm{~h}$. Control cells were treated with DMSO only. Live cell images were taken with confocal microscopy. The membrane ruffle localization of Cybr/ROM was lost in latrunculin A-treated cells compared to control cells. Bar $=10 \mu \mathrm{m}$.

Figure 2. Localization of GFP-Cybr/ROM and GFP-Cybr/ROM mutants to intracellular compartments. (A) GFP constructs of Cybr/ROM (+Type Cybr/ROM) and truncated proteins consisting of the leucine-rich (LEU) or PDZ (PDZ) domains were transiently transfected into H1299 cells and imaged by confocal microscopy. Wild-type Cybr/ROM and the LEU domain 
demonstrated similar cellular localization to vesicles, the cytoplasm and membrane ruffles while cells expressing the PDZ domain mutant stained membrane ruffles and the cytoplasm, lacking vesicular staining. Arrows and arrowheads indicate PM/cell ruffle and vesicular staining, respectively. Bar $=10 \mu \mathrm{m}$.

Figure 3. The function and spectra of Phamret and Phamret-Cybr/ROM. (A) The mechanism of Phamret activation. Phamret is composed of mse-CFP and PA-GFP. Before photoconversion, Phamret is in an inactive state and excitation of Phamret with a $458 \mathrm{~nm}$ laser result in emission at $485 \mathrm{~nm}$. After photoconversion of Phamret by a $405 \mathrm{~nm}$ laser, the structure of Phamret changes and FRET occurs from mse-CFP to PA-GFP. Subsequent excitation of Phamret with the $458 \mathrm{~nm}$ laser leads to emission at $510 \mathrm{~nm}$. This figure is adapted from Matsuda et al. (2008). (B) Emission spectra of Phamret in H1299 cells before and after photoconversion (PC) showing a shift in the emission peaks. (C) Cybr/ROM was cloned into the Phamret vector, the PhamretCybr/ROM plasmid was transfected into H1299 cells and the emission spectrum was read. The spectra showed an increase in the emission peak after photoconversion similar to Phamret. The schematic representation of Phamret and Phamret-Cybr/ROM.

Figure 4. Photoconversion of Phamret and Phamret-Cybr/ROM in H1299 cells. The region of interest (ROI) indicated by a circle was subjected to photoconversion by $405 \mathrm{~nm}$ light stimulation for $38 \mathrm{~ms}$ and photobleached by $515 \mathrm{~nm}$ laser irradiation for $2 \mathrm{~s}$. Excitation was performed with the $458 \mathrm{~nm}$ laser and the images were acquired in both the cyan $(485-500 \mathrm{~nm})$ and green $(500-$ $550 \mathrm{~nm}$ ) fluorescence channels. (A, B) Cyan and green channels represent mse-CFP and acceptor 
PA-GFP, respectively. The ratio of the two channels is presented in pseudocolour on the far right. In the ratio image, the ROI photoconverted by UV light and photobleached by $515 \mathrm{~nm}$ laser demonstrated a shift from cyan to yellow-red, then back to green-cyan, indicating conversion and recovery of Phamret. (C, D) The graphs illustrate the relative fluorescence intensities of Phamret and Phamret-Cybr/ROM before photoconversion (Pre PC), after photoconversion (Post PC) and after photobleaching (Post $\mathrm{PB}$ ) in ROIs. There was a decrease in cyan and an increase in green fluorescence Post PC, whereas recovery in cyan and loss in green fluorescence occurred Post PB. Bar $=10 \mu \mathrm{m}$

Figure 5. Tracking the translocation of Phamret and Phamret-Cybr/ROM from the cytoplasm to membrane ruffles in H1299 cells. (A, B) Confocal images were taken at $1 \mathrm{~s}$ intervals and represent donor mse-CFP (left) and acceptor PA-GFP (middle) and the ratio of the two channels is presented in pseudocolour (right). The inset images show the enlarged regions of membrane ruffles. In the Phamret images, ROI 2 was drawn on the photoconverted circular region, and ROI 3 and ROI 4 were placed on membrane ruffles and cytoplasm, respectively. In the PhamretCybr/ROM images, ROI 2 was set on the photoconverted circular region, and ROI 4 and ROI 5 were placed on membrane ruffles. (C) Fluorescence intensities of the ratios between the green and cyan channels for the Phamret images were plotted as a function of time. The emission ratios in ROI 2 (photoconverted region), ROI 3 (membrane ruffles) and ROI 4 (cytoplasm) showed that Phamret diffused within the cytoplasm of $\mathrm{H} 1299$ cells, but not to the membrane ruffling sites. (D) Fluorescence intensities of the ratios between the green and cyan channels for PhamretCybr/ROM were plotted over time. The emission ratios in ROI 2 (photoconverted region), ROI 4 (membrane ruffling sites) and ROI 5 (membrane ruffles) showed that Phamret-Cybr/ROM 
trafficked from the cytoplasm to the membrane ruffling sites in H1299 cells. Illustrated are also some parameters used for measurements displayed on Table 1. The transport time was measured using tPC-tROI where tPC and tROI were the time of occurrence of the highest green to cyan emission ratio at the photoconverted site and the ROIs, respectively. Velocity was calculated by dividing the distance travelled between the ROIs and the transport time. The residence time at ruffling sites is given by $\mathrm{T}=\mathrm{t}_{1 / 2}-\mathrm{t}_{\mathrm{ROI}}$, where $\mathrm{t} 1 / 2$ is the time of the selected membrane ruffles area when the emission ratio decreased to half of the maximum after photoconversion. Bar $=10 \mu \mathrm{m}$.

Figure 6. Trafficking of Phamret-Cybr/ROM from the membrane ruffling sites to the cytoplasm in H1299 cells. Phamret-Cybr/ROM was photoconverted at membrane ruffles and the pre- and post-photoconverted states were displayed as (A) confocal images of donor mse-CFP and acceptor PA-GFP, as well as the ratio image of the two channels in pseudocolour. The inset images represent the enlarged region of the ruffles. The images of Phamret-Cybr/ROM expressing H1299 cells before photoconversion and after photoconversion were taken every second. ROI 2 was set on the photoconverted circular region. ROI3 and ROI 4 were placed on opposing sides of ROI 2 on the PM. ROI 5 was placed in the cytoplasm. (B) The ratio of fluorescence intensities between the green and cyan channels was plotted over time. The emission ratios in ROI 2 (photoconverted region), ROI 3 (membrane ruffling sites), ROI 4 (membrane ruffling sites) and ROI 5 (cytoplasm) showed that Phamret-Cybr/ROM trafficked along the membrane ruffling sites and from the membrane ruffling sites to cytoplasm in H1299 cells. Bar $=10 \mu \mathrm{m}$. 
Supplementary Movie 1. Live cell movie shows the occurrence Cybr/ROM at the membrane ruffling sites and its presence in vesicles in H1299 cells. H1299 cells were transiently transfected with GFP-Cybr/ROM plasmids after plating in rat type I collagen-coated glass bottom dish for 24 h. After an overnight incubation, live cell imaging was performed on the Leica TSPII laser scanning microscope with a $60 \times$ water objective.

Supplementary Figure 1. The cloning of Cybr/ROM-Phamret. (A) The image illustrate the cloning position of Cybr/ROM within the pcDNA3-Phamret vector. (B) Cybr/ROM was amplified by PCR with the primers, CGG AAT TCG GTG GCA GCG GTG GCT CTT TAC AAA GGC TCC T and CAT CGC CTC GAG TCA AAA GCG ACT TTC TTC C, using the PCDNA3 GFP-Cybr/ROM plasmid as a template. The PCR product was purified by gel extraction. Lane (1), Cybr/ROM, and Lane (2), 100 bp DNA ladder. (C) Cybr/ROM and PCDNA3 Phamret-actin were digested with EcoRI and XhoI restriction enzymes. The restriction digestion products were purified by gel extraction and were electrophoresed. Lane (1), Cybr/ROM plasmid; Lane (2), the restriction products of PCDNA3 and, Lane (3), 1kb DNA ladder. Cybr/ROM was ligated into the plasmid containing Phamret and the ligation products were electrophoresed (D) Lane (1), Phamret-Cybr/ROM; Lane (2), 1 kb DNA ladder. (E) The ligation product was transformed into One Shot Top10 Competent Cells. Single colonies were cultured and the plasmids were purified using a mini-prep kit and amplified by PCR using the primers CGG AAT TCG GTG GCA GCG GTG GCT CTT TAC AAA GGC TCC T and CAT CGC CTC GAG TCA AAA GCG ACT TTC TTC C. Lane (1), 100 bp DNA ladder; Lane (2), PCR products and Lane (3), 1 kb DNA ladder. 
Yang et al. Figure 1

A

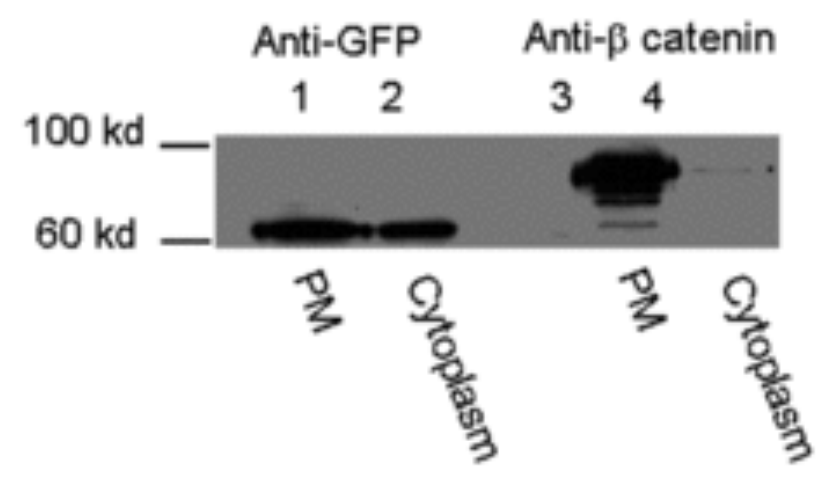

B

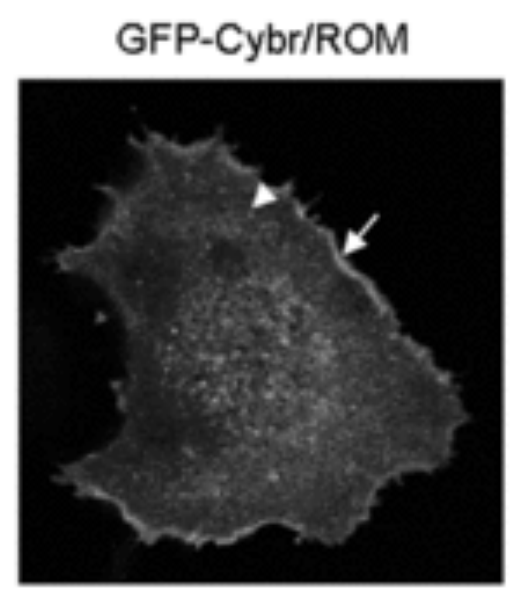

DIC

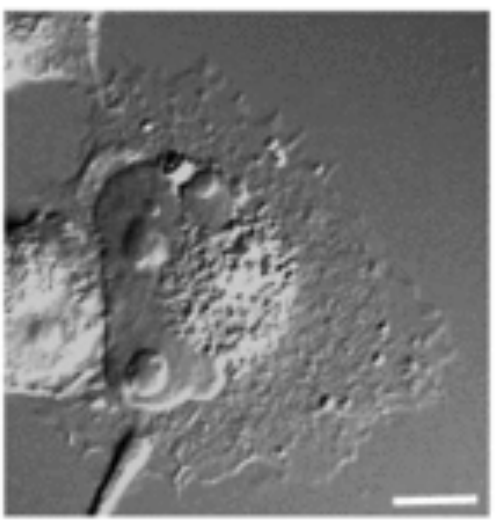

C

$\mathrm{CON}$

Latrunculin A
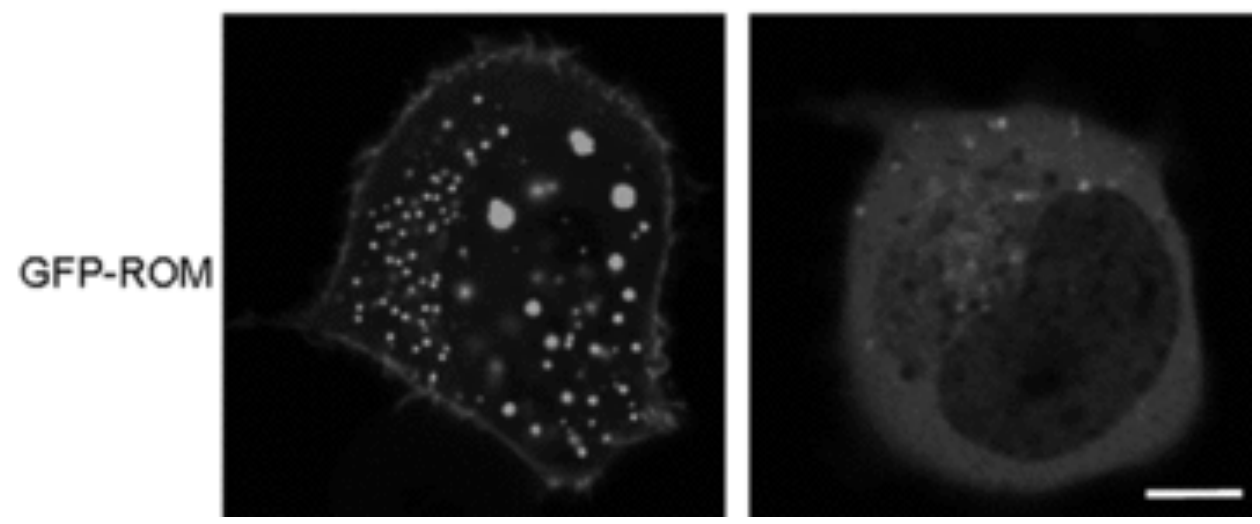


\section{Yang et al. Figure 2}

+Type Cybr/ROM-GFP
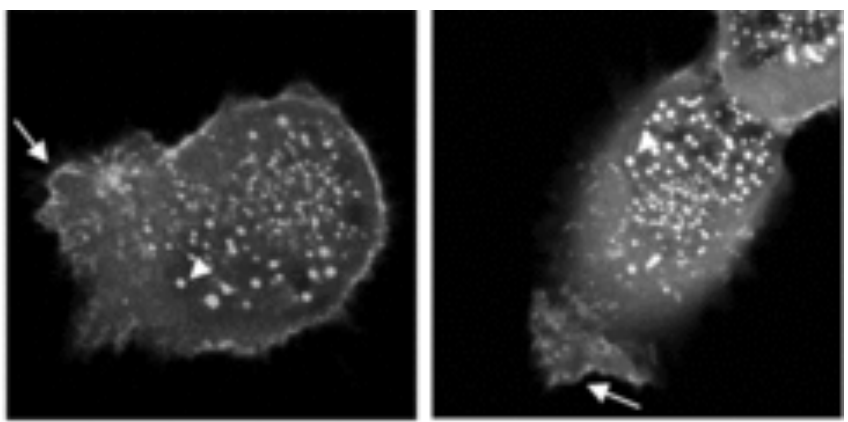

LEU-GFP
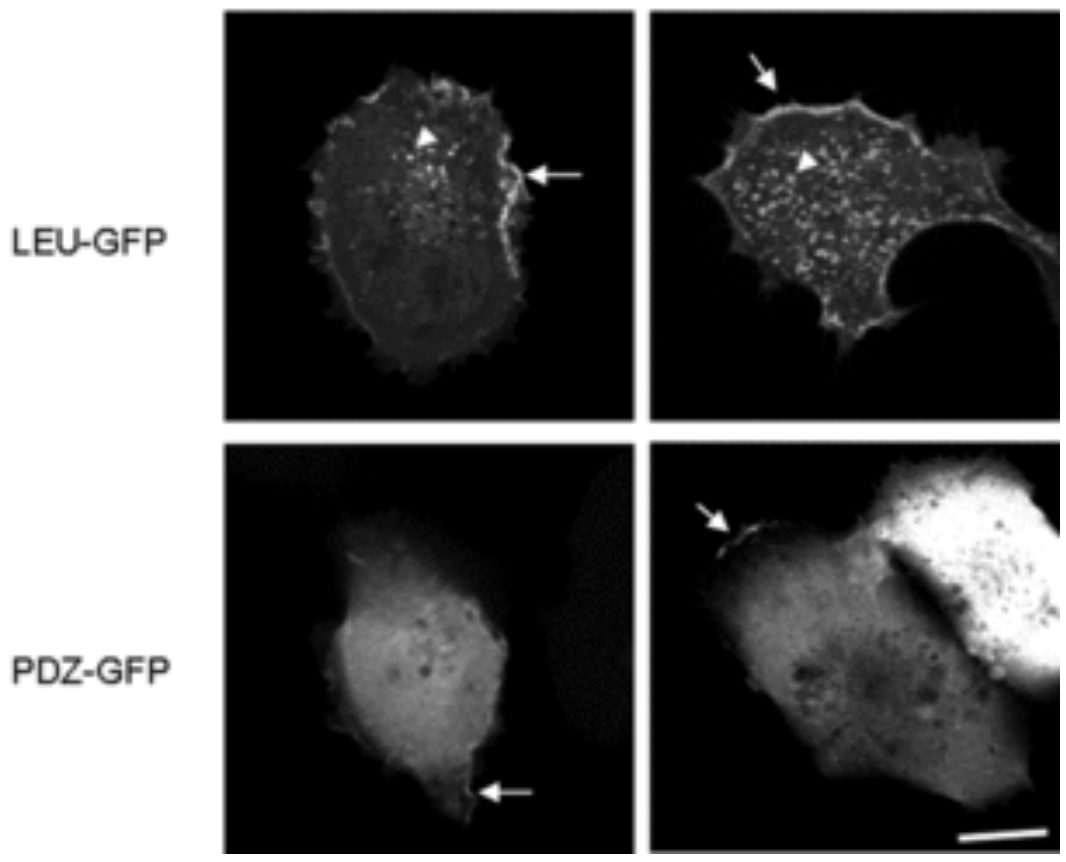
A

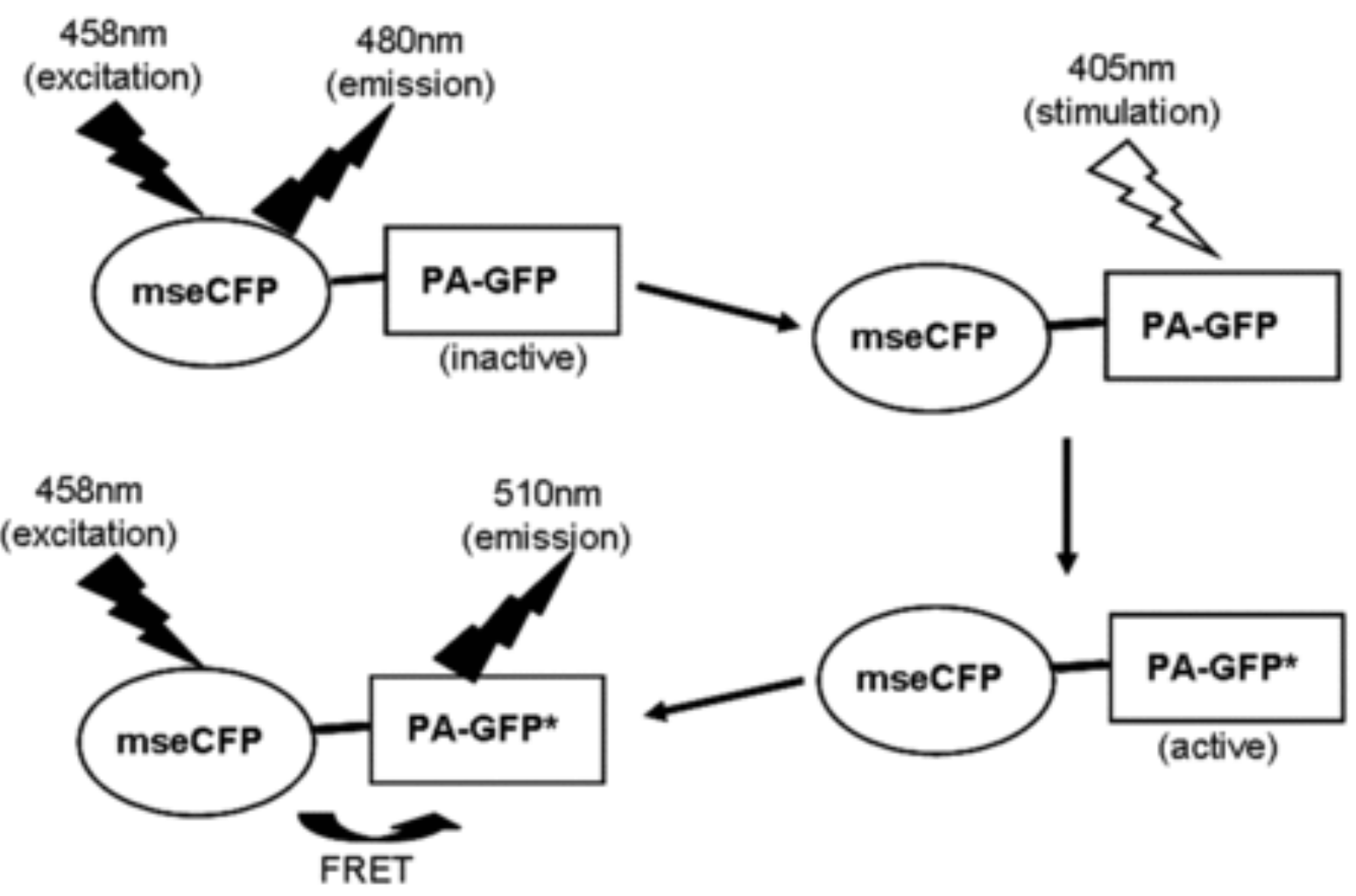

B

Phamret

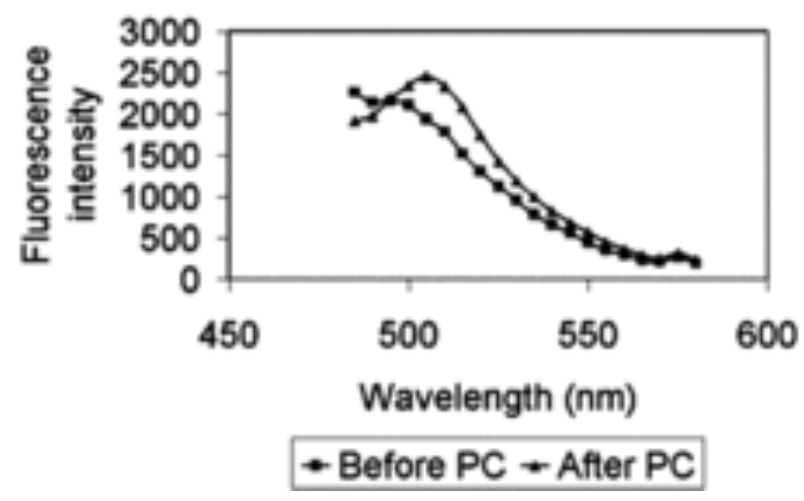

C

Phamret-Cybr/ROM

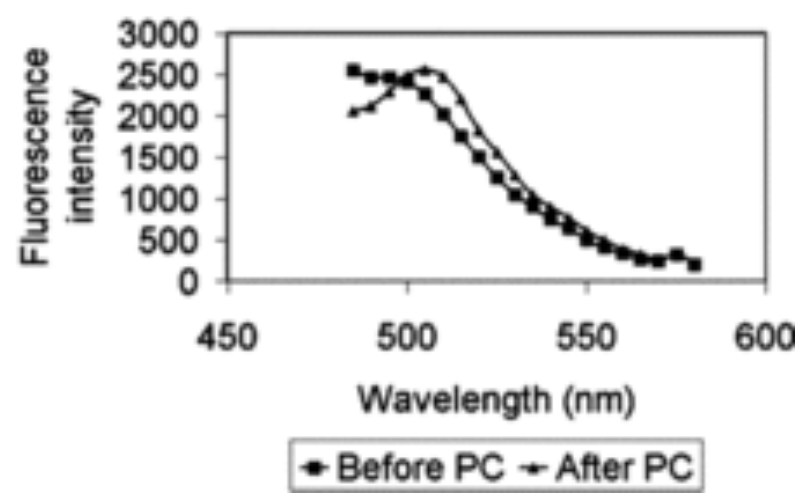




\section{Yang et al. Figure 4}

A

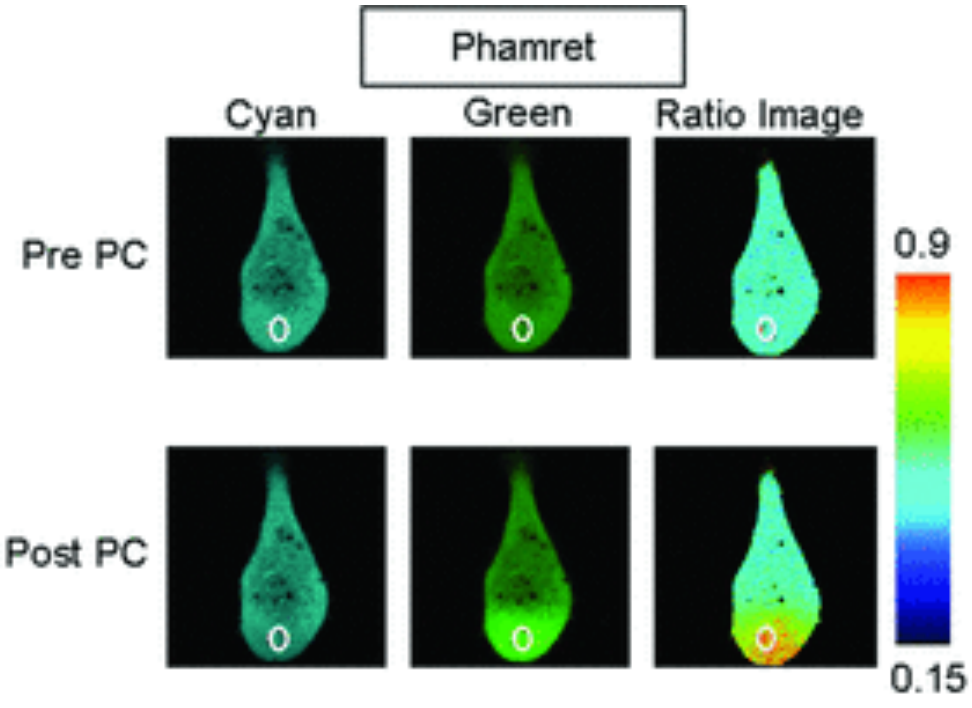

Post PB

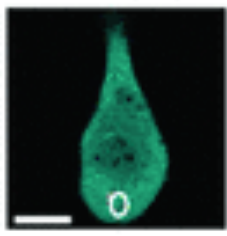

C

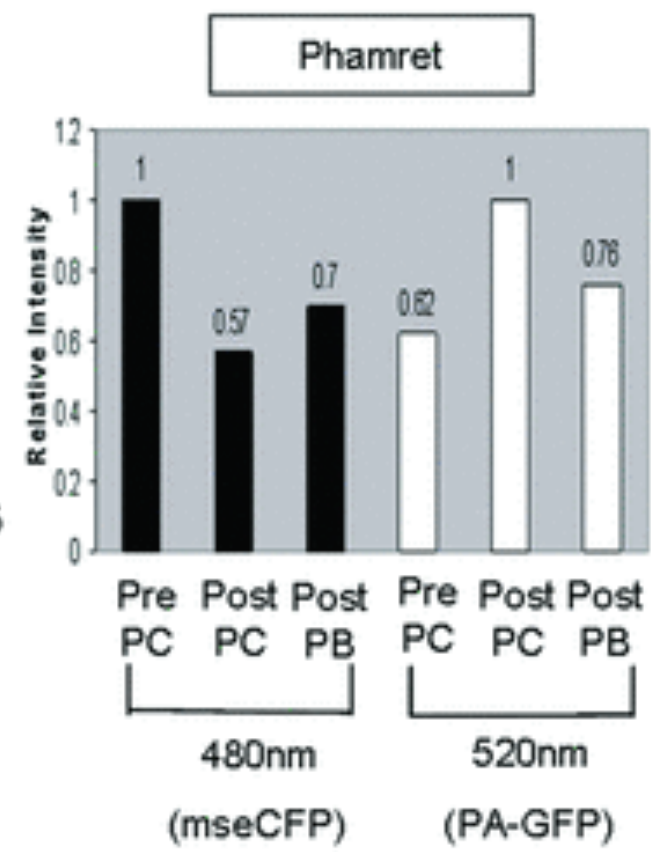

D

1.0

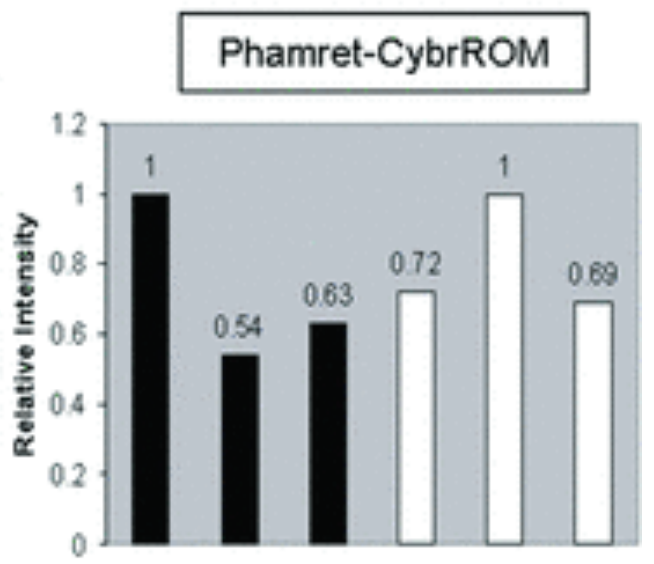

Pre Post Post Pre Post Post PC PC PB PC PC PB

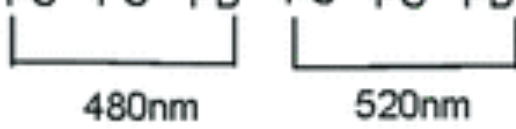

(mseCFP)

(PA-GFP) 


\section{Yang et al. Figure 5}

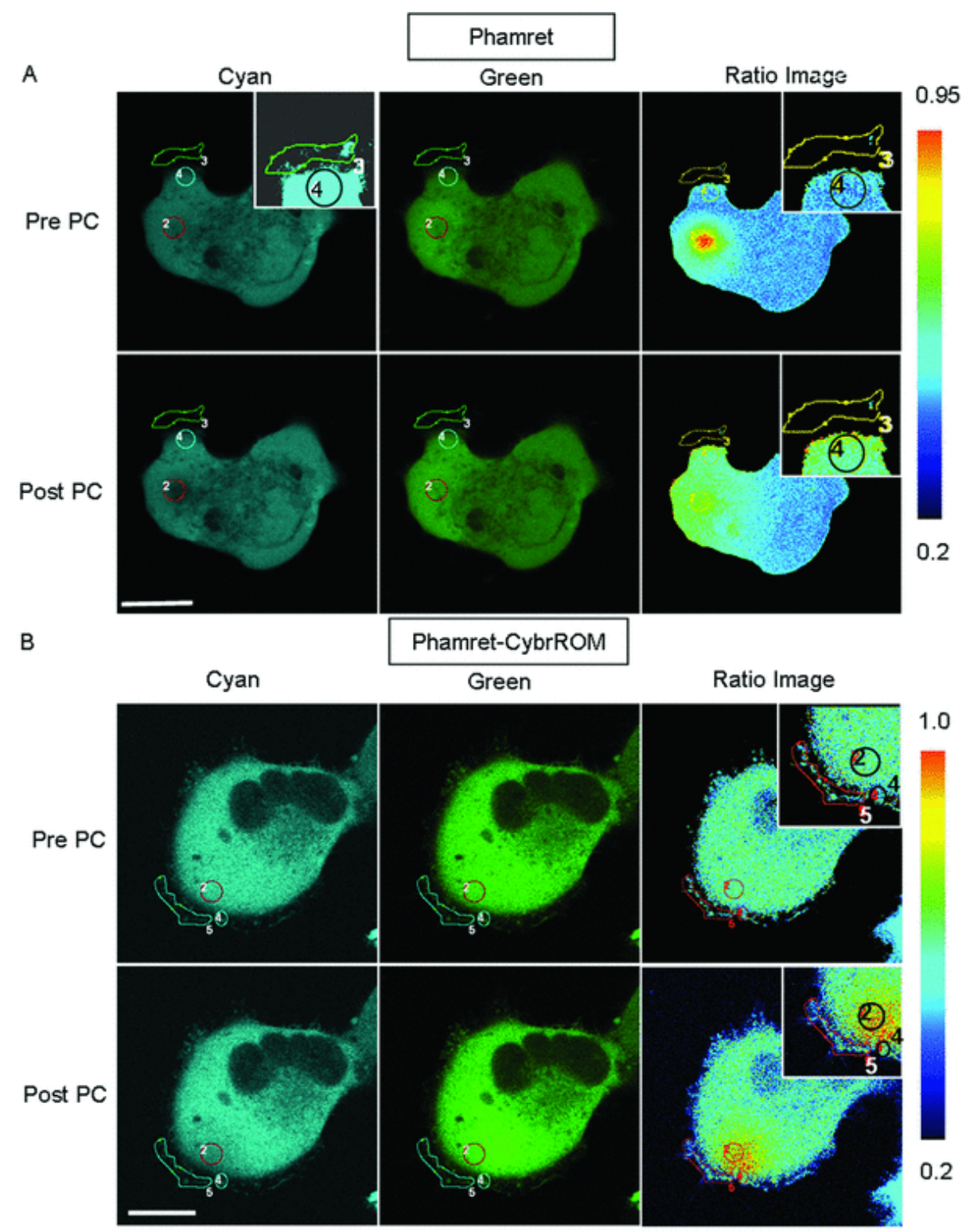

C
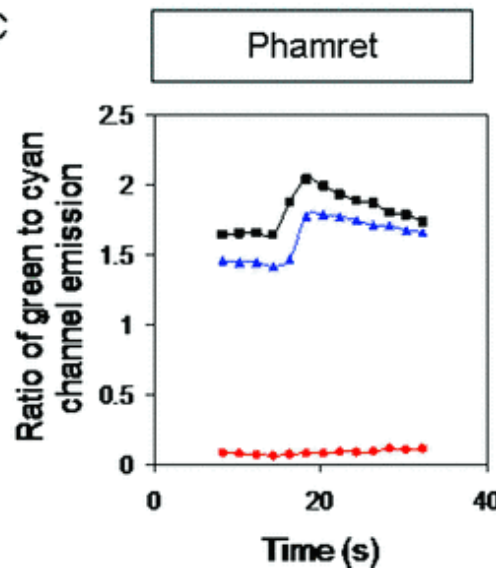

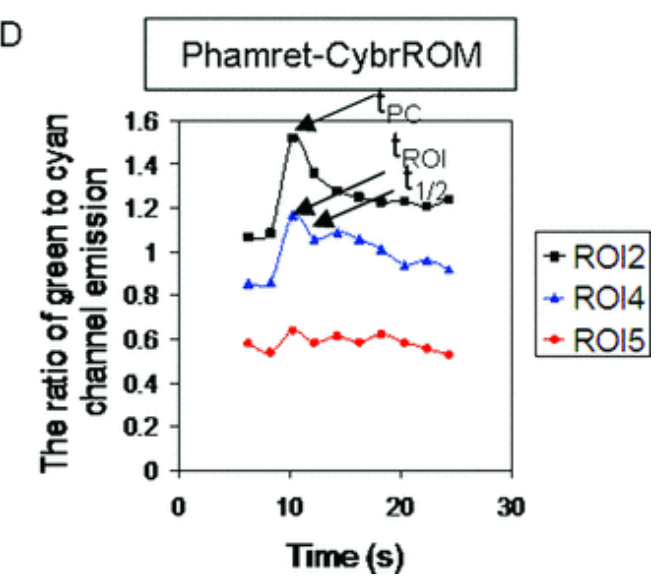




\section{Yang et al. Figure 6}

A

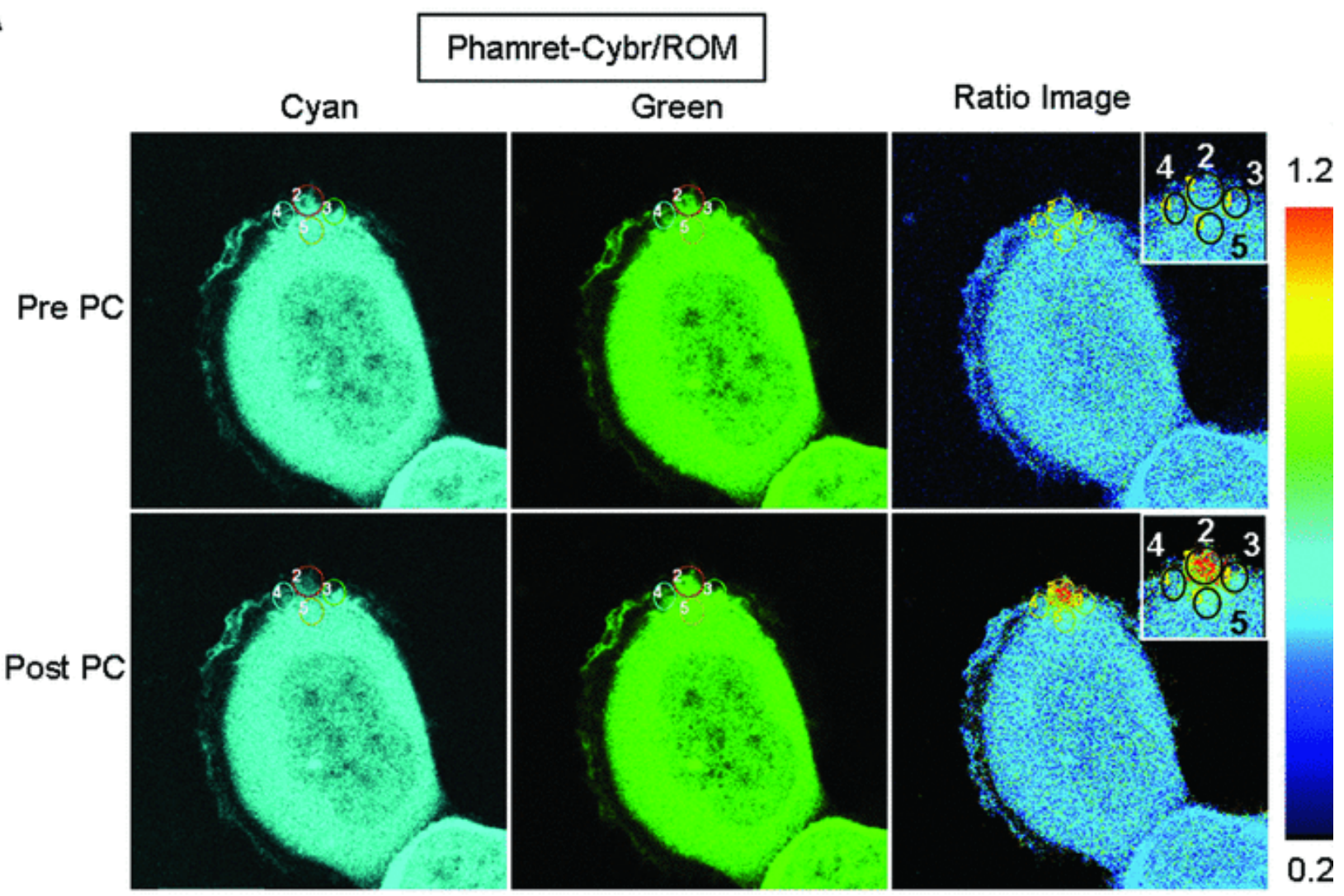

B

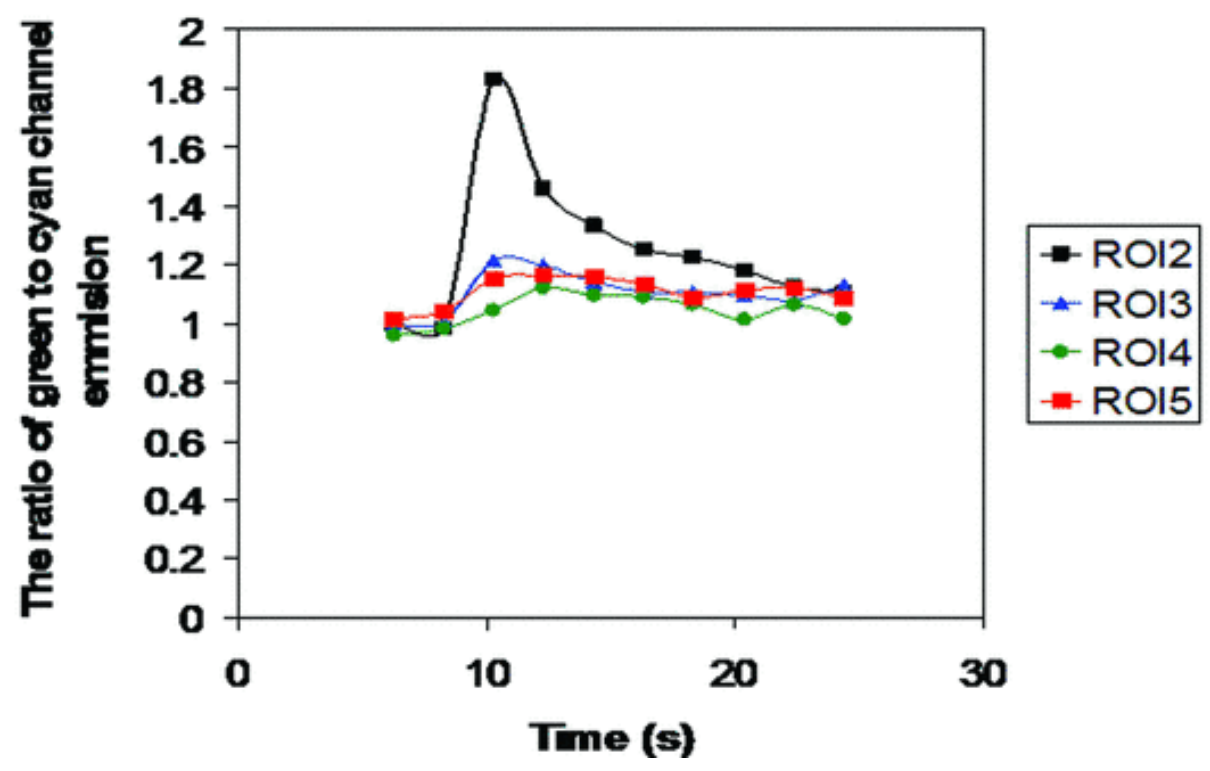




\section{Yang et al. Supplementary Figure 1}

A
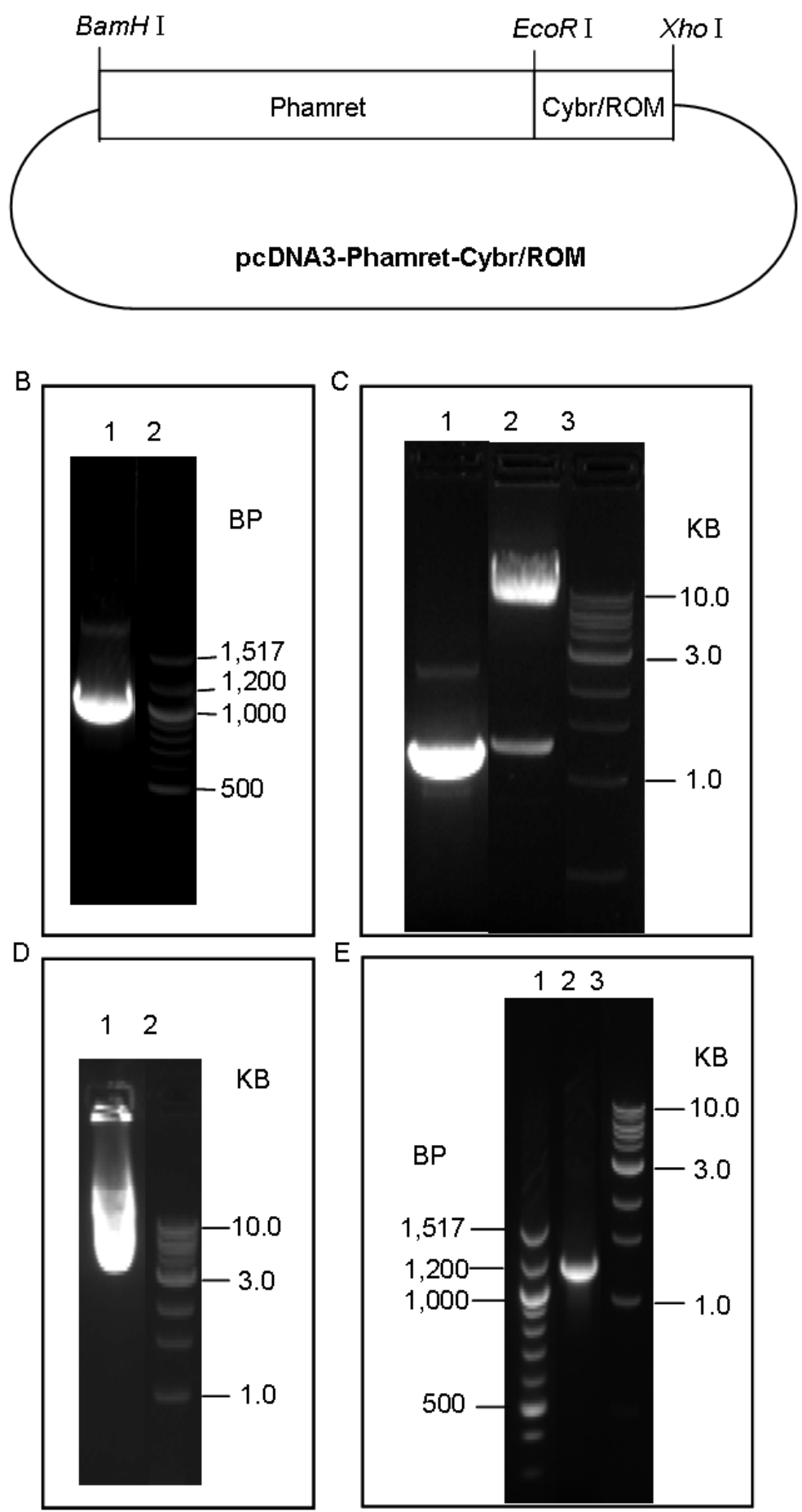

E

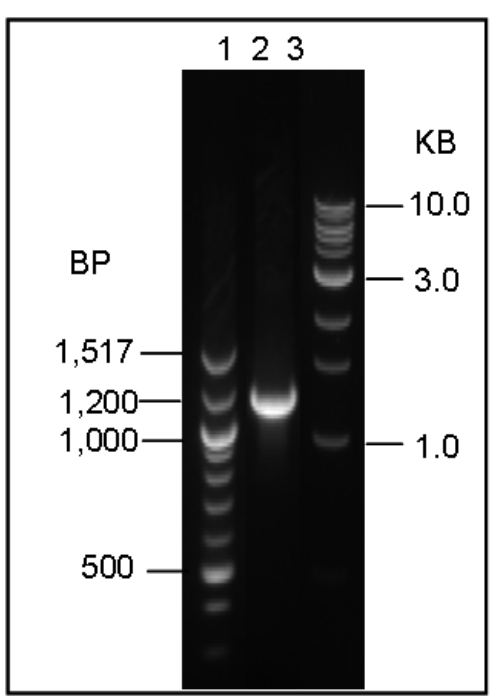

